\title{
Türkiye’nin 2008 Küresel Ekonomik Krizi ve Kovid-19 Kriziyle Mücadelesi
}

\section{The challenge of Turkey with 2008 Global Economic Crisis and Covid-19 Crisis}

Dilek Gürcün ${ }^{\mathrm{a}, *}$, Necmiye Cömertler ${ }^{\mathrm{b}}$

a Öğr. Gör. Aydın Adnan Menderes Üniversitesi, Nazilli Meslek Yüksekokulu, Dış Ticaret Bölümü, 09900, Aydın/Türkiye. ORCID:0000-0003-2418-2243

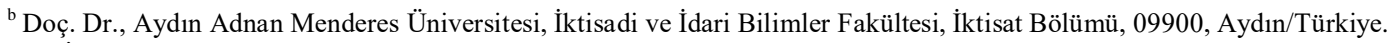
ORCID:0000-0002-0370-843X

\begin{tabular}{l} 
MAKALE BİLGİİ \\
Makale Geçmişi: \\
Başvuru tarihi: 01 Temmuz 2020 \\
Düzeltme tarihi: 27 Ekim 2020 \\
Kabul tarihi: 04 Kasım 2020 \\
\hline Anahtar Kelimeler: \\
Küresel Kriz \\
Kovid-19 \\
Ekonomi \\
Salgın
\end{tabular}

ÖZ

2001 krizinin ağır etkilerini henüz üzerinden atamadan 2008 Küresel Ekonomik Krizine yakalanan Türkiye şimdi de Kovid-19 virüsünün yol açtığı küresel ekonomik krizle mücadele etmektedir. Neredeyse 10 yılda bir, yeni bir krizle yüzleşen Türkiye, bir yandan bu krizlerle mücadelede deneyim, hareket kabiliyeti ve direnç kazanırken bir yandan da krizlerin yıkıcı etkileri ve toplumsal travma, gelir dağılımında ileri düzeyde bozulma, siyasal ve ekonomik sorunların etkisi ile kapıldığ 1 bu girdaptan kurtulmaya çalışmaktadır. Bu çalışmada ilk olarak 2008 Küresel Ekonomik Krizinin etkileri ve sonuçları incelenmekte daha sonra genel olarak dünyanın 1929 Büyük Buhranından beri karşılaştığı en büyük ekonomik kriz olarak değerlendirilen Kovid-19 Küresel Ekonomik Krizi ele alınarak, bu krizin Türkiye'ye etkileri araştırılmaktadır.

\section{ART ICLE INFO}

Article history:

Received 01 July 2020

Received in revised form 27 October 2020

Accepted 04 November 2020

\section{Keywords:}

Global Crisis

Covid-19

Economy

Pandemics

\section{A B S T R A C T}

Turkey captured the 2008 Global Economic Crisis without overcoming the heavy effects of the 2001 crisis is now struggling with the global economic crisis caused by the Covid-19 virus. Turkey facing a new crisis in almost every 10 years, on the one hand is to gain experience, mobility and resistance in dealing with this crisis, on the other hand, is trying to get out of this vortex caused by destructive effects of the crisis and social trauma, advanced deterioration in income distribution, political and economic problems. First, the effects and consequences of the 2008 Global Economic Crisis are examined in this study. Then, the Covid-19 Global Economic Crisis, which is generally considered the biggest economic crisis in the world since the Great Depression of 1929, is discussed. The effects of the crisis in Turkey are being investigated.

\section{Giriş}

Dünya, FED Eski Başkanı Greenspan tarafindan "II. Dünya Savaşı'nın yol açtığı krizden sonra yaşanan en büyük kriz" olarak tanımlanan 2008 Küresel krizini atlatamadan Kovid-19 Küresel Krizi ile yüzleşmiştir. Bu kimilerine göre kapitalizmin artık dönmekte zorlanan çarklarının yarattığı ve dünyayı süreleri gittikçe kısalan aralıklara pençesine alan kapitalist sistemin bir sorunudur; kimine göre ise iktisat biliminin sınırlı kaynaklarla sınırsız insan ihtiyaçlarını karşılamakta çözüm üretememesinin beklenen sonucudur. Hangi açıdan bakılırsa bakılsın her kesimin üzerinde uzlaştığı iki nokta vardır. Birincisi dünyadaki teknolojik gelişmeler ve bilgi yayılımının körüklediği korkunç tüketim çılgınlığı, ikincisi ise insanların yaşanılan onca acı tecrübeye karşı ders alma, öngörme ve önlem alma mekanizmalarının işlememesidir. Gelir dağılımının sadece ülke içinde değil ülkeler arasında da adeta bir çı̆̆ gibi büyüdüğü dünyada, yönetenlerin

* Sorumlu yazar/Corresponding author.

e-posta: dgurcun@adu.edu.tr 
mutlak gücü ya da yönetilenlerin mutlak acizliği olgusu yerini her kesimin kazandığı ve başarının ya da başarısızlığın beraberce kucaklanması gereken bir olgu olduğu gerçeğine bırakmaktadır. Gelecek bu olgunun ne kadar çabuk anlaşılıp ne kadar çabuk hayata geçirileceğine göre şekillenecektir.

Bu çalışma ile Türkiye'nin yaşadığg iki büyük küresel kriz ele alınmış ve bu krizlerle mücadelesi ortaya konulmaya çalışılmıştır. Çalışma ile ayrıca gelecekte yaşanacak krizleri anlamak ve çözüm üretmek için yapılacak çalışmalara 1şık tutmak amaçlanmaktadır.

\section{2008 Küresel Ekonomik Krizi Doğuşu ve Küresel Boyut Kazanması}

Dünyayı kasıp kavuran büyük bunalımın ilk kez Amerika'da ortaya çıkıp önce Avrupa'yı sonra tüm dünyayı etkilemesi gibi Küresel Ekonomik kriz de önce Amerika'da ortaya çıkmış ve hızla yayılmıştır. Büyük Buhran'ın fitilini 1920'li y1llarda Florida'da yaşanan arazi balonunun ateşlediği gibi (İsmailoğlu ve Çetin, 2012: 62) Küresel Ekonomik Krizin fitilini de yine gayrimenkul sektörü ateşlemiş ve bu nedenle tarihe "Mortgage krizi" olarak geçmiştir.

ABD Başkanı Bush'un "Fakirleri Ev Sahibi Yapma Projesi" gibi talebi canlandırıcı, "Irak'a Demokrasi Götürme" adı altında savunma harcamalarını arttırıcı uygulamaları bütçe açığını artırmış, ABD Merkez Bankası (FED)'nın faizleri düşürme politikası ile birleşince arzın talebi karşılayamaması sonucunda fiyatlar hızla artmıştır (Yildiz ve Durgun, 2010: 3-4).

ABD'de başlayıp ilk işaretleri 2006 yılında ortaya çıkan bu gelişmeler, 2007 yılında kredi krizine, sonrasında likidite krizine dönüşmüştür. Krizin finansal piyasalara sıçraması uzun sürmemiş ve ardından da 2008 yılı içerisinde reel sektörü de etkisi altına almıştır (Karabıyık ve Anbar, 2010: 44-45).

Menkulleştirilen konut kredilerinin bu yolla türev ürünlere çevrilmesi ve finansal kurumların bu ürünlere risk kontrolü yapmaksızın yatırım yapması, krize bambaşka bir boyut kazandırmıştır. Kriz, konut kredisinin yarattığı krizden ziyade bu krediye dayalı türev ürünlerin ortaya çıkardığı bir krize doğru evrilmiştir. Bu türev ürünleri portföylerinde barındıran tüm bankalar, ürünlerin değerlerinin düşmesiyle zor durumda kalınca kriz ABD sınırlarının dışına taşarak küresel bir boyut kazanmıştır (Polat, 2018: 177).

Fitili ABD'de de ateşlenen ve önce Euro bölgesine sonra diğer gelişmekte olan ülkelere yayılan kriz, gelişmekte olan ülke borsalarına da yansımış ve yaşanan değer kaybını yabancı sermaye girişlerindeki azalma takip etmiştir. Döviz kurundaki kaçınılmaz yükselme finansal kuruluşların bilânçolarını bozmuştur. Finansal piyasalarda yaşanan bu dalgalanma, makro ekonomik göstergelerde de bozulmaya yol açmıştır (Takım, 2011: 338).

Tablo 1'de de görüleceği gibi gelişmiş ülke ekonomilerinde 2009 yılında \% 3,2 oranında küçülme meydana gelmiştir. Gelişmekte olan ülkelerde ise \% 2,4 oranında büyüme dikkat çekerken dünya hasılasında toplam küçülme \% 0,6 olarak gerçekleşmiştir. Gelişmiş ülkeler içerisinde küresel kriz ortamından en fazla etkilenen ülke \% 5,2'lik küçülme ile Japonya olmuştur. Gelişmekte olan ülkeler içerisinde ise Rusya \% 7,9 oranında küçülmüştür. Çin ve Hindistan gibi Asya ülkelerinin başı çektiği gelişmekte olan ülkelerde ise $\%$ 2,4 oranında bir büyüme sağlanmıştır. Bunun yanında gelişmekte olan ülkeler sınıfına giren bazı Latin Amerika ve Avrupa Birliği üyesi olmayan ülkelerde ekonomik anlamda küçülme olmuştur (TOBB 2009:3).

Tablo 1. Dünya Ekonomisinde Üretim Artıș Hızı (Değișim \%)

\begin{tabular}{|c|c|c|c|}
\hline & 2007 & 2008 & 2009 \\
\hline Dünya Üretimi & 5,2 & 3,0 & $-0,6$ \\
\hline Gelişmiş Ülke Ekonomileri & 2,8 & 0,5 & $-3,2$ \\
\hline $\mathrm{ABD}$ & 2,1 & 0,4 & $-2,4$ \\
\hline Euro Alanı & 2,8 & 0,6 & $-4,1$ \\
\hline -Almanya & 2,5 & 1,2 & $-5,0$ \\
\hline -Fransa & 2,3 & 0,3 & $-2,2$ \\
\hline -İtalya & 1,5 & $-1,3$ & $-5,0$ \\
\hline -İspanya & 3,6 & 0,9 & $-3,6$ \\
\hline Japonya & 2,4 & $-1,2$ & $-5,2$ \\
\hline İngiltere & 2,6 & 0,5 & $-4,9$ \\
\hline Kanada & 2,5 & 0,4 & $-2,6$ \\
\hline Gelişmekte Olan Ülke Ek. & 8,3 & 6,1 & 2,4 \\
\hline Gelişmekte Olan Asya Ek. & 10,6 & 7,9 & 6,6 \\
\hline -Çin & 13,0 & 9,6 & 8,7 \\
\hline -Hindistan & 9,4 & 7,3 & 5,7 \\
\hline -ASEAN-5* & 6,3 & 4,7 & 1,7 \\
\hline Latin Amerika & 5,8 & 4,3 & $-1,8$ \\
\hline -Brezilya & 6,1 & 5,1 & $-0,2$ \\
\hline -Meksika & 3,3 & 1,5 & $-6,5$ \\
\hline Geçiş Süreci Ülkeleri & 8,6 & 5,5 & $-6,6$ \\
\hline -Rusya & 8,1 & 5,6 & $-7,9$ \\
\hline
\end{tabular}

(*): Endonezya, Malezya, Filipinler, Tayland ve Vietnam Kaynak: IMF, World Economic Outlook, April 2010 (TOBB 2009 Ekonomi Raporundan alınmıştır).

1.1. 2008 Küresel Krizinin Sonuçları ve Çözüm Arayışları: Dünyanın 1930'lardan sonra karşılaştığı en büyük finansal şok olan kriz, ekonomilerinin daralmasını beraberinde getirmiştir. Gelişmiş ülkelerin finans sektöründe, gelişmekte olan ülkelerin reel sektöründe hissedilen kriz, döviz kurları, sermaye akımları ve ticaret hacimlerini aşağı yönlü etkilemiştir. Krizle birlikte ülkelerdeki işsizlik oranı artmakla kalmamış bütçe açıkları da yükselmiştir.

Krizle tüm ülkeler merkez bankaları aracılığıyla mücadele etmiş, hükümetler birbiri ardına kurtarma paketleri açıklamıştır. İç talebi canlandırmak ve kamu yatırımlarını arttırmak öncelikli politikalar arasında yer almıştır.

Krizle mücadelede Japonya, ABD ve Avrupa Merkez Bankaları aracılığı ile 350 milyar dolar piyasaya sürülmüş ve faiz oranları düşürülmüştür (Duman ve Iş1k, 2011: 97). Alınan bu önlemlerin yanı sıra ekonomiyi canlandırmaya yönelik paketler, vergi indirimleri, devletleştirme çalışmaları, sübvansiyonlar ve kamu harcamalarını arttırmak krizi çözmede başvurulan yöntemler arasında yer almıştır. Bu çalışmalar krizin yıkıcı etkilerini tam olarak ortadan kaldırmasa da daha az bankanın iflası ve daha fazla şirketin batmasının önüne geçmekte etkili olmuştur (Ay ve Uçar, 2015: 22-23). 
Küresel finansal krizle mücadele eden $\mathrm{AB}$ üyesi ülkeler tüm bu önlemlerin yanı sıra krizle mücadelede üye ülkelerin rekabet gücünün arttırılması ve ekonomi yönetimlerinin güçlendirilmesi noktasında da önlemler almıştır (Yavuz, Şataf ve Kır, 2013: 150-151).

1.2. 2008 Küresel Krizinin Türkiye’ye Etkileri ve Çözüm Arayışları: Türkiye de krizden önemli ölçüde etkilemiş, krizden en çok etkilenenler ise ülke nüfusun büyük bölümünü oluşturan düşük gelir grubu olmuştur. 2001 krizinin yarattığı tahribatı tam olarak onaramadan, kapısını çok şiddetli çalan bu krizden büyük oranda zarar görmekle beraber 2001 krizinin deneyimleri sayesinde Küresel Krize birçok Avrupa ülkesine göre daha kolay adapte olabilmiştir. Gördükleri en büyük kriz, 1929 Büyük Buhranı olan ve İkinci Dünya Savaşı ile büyük bir yoklukla mücadele eden $A B D$ ve Avrupa ülkeleri, 2008 yılına kadar bir daha büyük bir kriz yaşamamışlardır. Bu nedenle kriz onları hazırlıksız yakalamıştır.

Türkiye'nin ihracat rakamlarının büyük çoğunluğunu Avrupa ile yaptığı ihracat oluşturmaktadır. Bu nedenle Avrupa'daki durgunluk ve büyüme rakamlarının aşağı yönlü seyri doğal olarak Türkiye'nin ihracat ve ithalatını da etkileyerek büyümeyi geriletmiştir. Türkiye'nin bankacılık sistemi, 2001 krizinde yaşadığı tecrübeleri, 2008 krizine taşımış ve o krize yönelik geliştirdiği tedbirleri 2008 krizinde hayata geçirmiştir. Türkiye'nin krizde elini güçlendiren diğer bir etken de krizi körükleyen türev ürünlerin, varlıkları içinde olmamasıdır. Ayrıca bu süreçte BDDK da, 2008 yılı karlarını dağıtmayıp, kredi yapılandırmaları noktasında doğru kararlar almıştır. $\mathrm{Bu}$ dönemde bankaların hiç birine fon sağlanmamıştır (Demirbaş ve Sezgin, 2010: 145-146).

Türkiye ekonomisi 2008 krizine kadar 1999 yılında, 2000 yılında ve 2001 yılında üç kriz yaşamıştır. Bu krizlerin tümünde dış desteğe ihtiyaç duyarak IMF ile anlaşma imzalamış ve pek de başarılı olmayan istikrar programları uygulamıştır. Türkiye, 2008 krizini ise IMF ile stand-by anlaşması imzalamadan aşmaya çabalamıştır.

Türkiye'de 2008 krizinin reel sektöre yansıması, GSYİH büyüme hızının yılsonu itibariyle \% 0,9'a gerilemesi ile yaşanmıştır (Yıldırım: 2010: 49-51). Merkez bankası, para politikası kapsamında 2008 küresel krizinde likidite yönünden sıkışan piyasaların rahatlaması için tarihi seviyelerde faiz indirimi gerçekleştirmiş, bankaların zorunlu karşılık oranlarını düşürmüş, ihracat döviz reeskont kredi limitini yükseltmiştir. Maliye politikası kapsamında da adımlar atılmış ve bazı sektörlerde vergi indirimleri uygulanarak iç talep canlandırılmaya çalışılmıştır. İstihdamı artırma amaçlı olarak sosyal güvenlik primlerinin kadınlar ve gençler için azaltılarak Hazine tarafindan karşılanması sağlanmıştır. Ayrıca üreticilerin sosyal güvenlik primlerinin bir kısmı devlet tarafindan karşılanmıştır (Buluş ve Kabaklarlı, 2010: 17-18).

2001 krizi sonrası Türkiye, uluslararası piyasalarda yaşanan finansal genişlemenin etkisiyle maliyeti düşük kredi imkânına da kavuşmuştur. Dış açıklar, yüksek faizler nedeniyle sürekli artmış ve bu açıklar Türkiye'ye akan sıcak parayla, özelleştirmelerle ve şirket birleşmelerinden kaynaklanan doğrudan yatırımlarla karşılanmaya çalışılmıştır. Türkiye'nin dış borcu yükselmiş ve 2002'nin son çeyreğinde toplam diş borç stoku 129.6 milyar dolardan 2008'in ikinci çeyreğinde 284.4 milyar dolara çıkmıştır (Yeldan, 2009: 17-18). 2008'in son çeyreğinde Türkiye brüt dış borç stoku 280.4 milyar dolar olarak gerçekleşmiştir. Aşağıdaki tablo, 2002-2008 yılları arasında Türkiye'nin son çeyreklerdeki dış borç stoklarını göstermektedir.

Tablo 2. Türkiye Brüt Dış Borç Stoku (Milyon ABD Doları)

\begin{tabular}{ll}
\hline Ceyrek Dönemler & Türkiye Brüt D1ș Borç Stoku \\
\cline { 2 - 2 } 2002 Ç4 & 129.601 \\
2003 Ç4 & 144.179 \\
2004 Ç4 & 161.159 \\
2005 Ç4 & 170.780 \\
2006 Ç4 & 208.007 \\
2007 Ç4 & 249.942 \\
2008 Ç4 & 280.424
\end{tabular}

Kaynak: T.C. Hazine ve Maliye Bakanlığı, 2020

(https://www.hmb.gov.tr/kamu-finansmani-istatistikleri)

Küresel kriz sürecinde, Türkiye diğer ülkelerin aksine finans piyasalarına yönelik kurtarma paketi açıklamamıştır, çünkü 2001 krizinde bu paketleri kamu bütçesine yükünü göz ardı ederek uygulamıştır. Bu dönemde Türkiye'nin hayata geçirdiği uygulamalarla bankaların sermaye yeterliliğine yönelik düzenlemeler ve yabancı para cinsi likidite oranlarına yönelik düzenlemeler, Türkiye'de bankacılık sektörünün şoklara dayanıklılı̆̆ını arttırmıştır. $\mathrm{Bu}$ çalışmalara 2008 yılından sonra alınan önlemler de eklenince Türkiye ekonomisi hızlı bir toparlanma sürecine girmiştir (Öztürk vd., 2012, s. 303).

\section{Küresel Pandemi: Kovid-19 ve Küresel Kriz}

Çin Halk Cumhuriyeti'nin 11 milyon nüfusa sahip Wuhan kentinde Aralık ayında başlayan ve tüm dünyaya büyük bir hızla yayılan Yeni tip Coronavirus yayılım hızına paralel ölüm hızıyla da dikkatleri üzerine çekmeyi başardı. Dünya Sağlık Örgütü (WHO), 26 Nisan 2020 tarihinde yayınladığı 97 sayılı durum raporunda yer alan bilgilere göre, 2.804.796 kişiye Yeni Coronavirus tanısı kondu ve bu kişilerden 193.710'u hayatını kaybetti (WHO, 2020).

ABD'den sonra 14 trilyon dolarlık GSYİH ile dünyanın ikinci büyük ekonomisi olan Çin, Coronavirus'ün yeni tipi Kovid-19 nedeniyle ekonomik olarak zor günler yaşamaktadır. Çin'in dünyanın pek çok ülkesi ile ticaret, yatırım ve üretim ağı düşünüldüğünde Çin'in ekonomisindeki bu kötüye gidişin dünya ülkelerinin tümünü etkisi altına alması kaçınılmaz görünmektedir (Dağlı, 2020: 7).

İnsanların hızla hastalanmaları ve tedavi süreçlerinin uzaması sağlık sektörüne büyük yük getirirken, dışarı çıkma yasakları ve evde kalma uygulamaları nedeniyle de üretim sektörü büyük darbe almıştır. Çalışamayan işletmelerin kapanması ve çok sayıda insanın işsiz kalması ile talep düşmüştür. Ödenemeyen krediler ve yükselen riskler finans sektörünü zor bir sürece doğru hızla sürüklemeye başlamıştır. Ekonomideki daralmadan tüm 
sektörler etkilenirken hükümetler evde tutmak zorunda kaldıkları kitleler için nakdi ödeme yapma ve vergilerde kısıntıya gitme mecburiyeti ile karşı karşıya kalmıştır. Giderek artan bir bilinmezlik tablosu oluşmuştur. Bu bilinmezliğin en önemli sebebi sürecin sınırlarını kimsenin çizememesidir. Dünyada yaşanan bu belirsizlik, IMF'nin hesapladığı Dünya Belirsizlik Endeksi'ne ve onun alt endeksi olan Dünya Pandemi Belirsizlik Endeksi'ne de yansımış durumdadır.

Economist İstihbarat Birimi (EIU) tarafından ülke raporlarında geçen "belirsizlik" kelimesi sayısının, ülke milli gelirleriyle ağırlıklandırılması yoluyla hesaplanan Küresel Belirsizlik Endeksi'nin bir alt endeksi olan ve ülke raporlarında pandemi veya salgınlarla ilgili olarak "belirsizlik" ten kaç kez bahsedildiği raporlanan Dünya Pandemi Belirsizlik Endeksi, IMF (Uluslararası Para Fonu) tarafindan açıklandı.

1996 yılından itibaren yayınlanan ve 143 ülkeyi kapsayan bu endeksin sonuçlarına göre, 31 Mart 2020 sonu itibariyle Coronavirus pandemisinin neden olduğu belirsizlik, SARS salgını sırasındaki belirsizlik oranının üç katı ve Ebola salgını sırasındaki boyutun yaklaşık 20 katıdır (Grafik 1). IMF'ye göre, Coronavirus etrafindaki belirsizlik seviyesi, vakalar arttıkça yüksek kalmaya devam edecektir. Bu nedenle de küresel çapta koordineli adımlar atılması gerekmektedir (IMF, 2020).

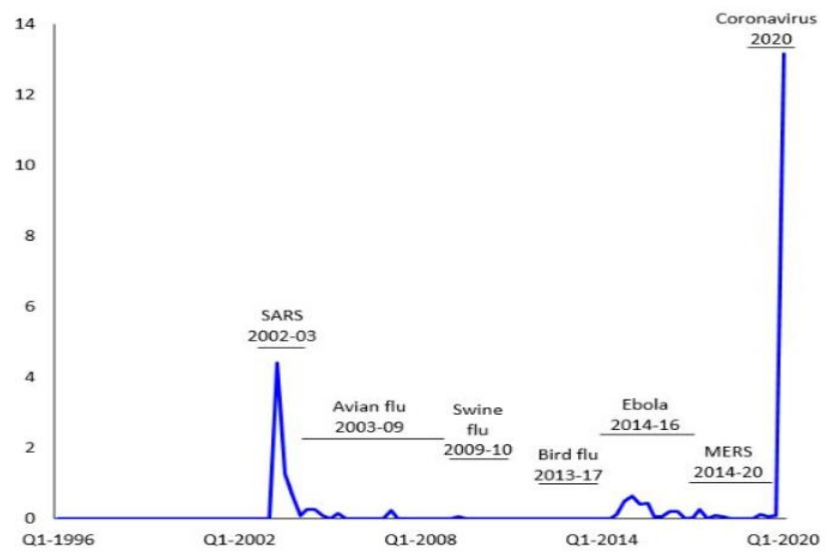

Grafik 1. Dünya Pandemi Belirsizlik Endeksi (Kaynak: IMF, 2020 https://blogs.imf.org/2020/04/04/global-uncertainty-related-tocoronavirus-at-record-high/)

\subsection{Kovid-19 Küresel Krizinin Diğer Küresel Krizlerden Fark1}

Küresel krizleri diğer krizlerden ayıran en önemli fark tüm dünyayı hem ekonomik hem toplumsal hem de siyasal olarak bütünüyle etkilemesidir. Kovid-19'u diğer küresel krizlerden ayıran fark ise olayın çevresel, yaşamsal ve felsefik boyutlarının dünyayı adeta bir çağ açıp bir çağ kapatacak düzeyde etkilemesidir.

Acemoğlu ve Robinson'un Ulusların Düşüşü kitabında altını çizdiği gibi, "İktisat genellikle siyaseti göz ardı eder fakat siyaseti anlamak dünya eşitsizliğini açıklamak için elzemdir" (Acemoğlu ve Robinson 2016: 70). Bu açıdan bakıldığında Kovid-19 Küresel Krizinin ekonomik etkilerini doğru anlamak için iktisadın konuya, siyasal, sosyal, kültürel hatta felsefi boyutlarını da ele alarak bütünsel bir bakış açısıyla yaklaşması gerekmektedir.

İnan (2020), Corona ile dünyanın adeta yeni bir çağa uyandığının altını çizerek artık Corona'dan önce Corona'dan sonra diye bir söylemin her alanda yineleneceğini kaydetmektedir. İnsanlığın boş bulunmazsa daha güçlü bir dünyaya uyanacağının da altını çizmektedir.

İnsanların sınırsız ihtiyaçlarının sınırlı kaynakları tükettiği, çevresel kirliliğin ve bireyselleşmenin arttığı, dünyanın hızla sona doğru yaklaştığı hatta yenidünya arayışlarının hız kazandığ1 günümüzde Yeni Coronavirus, insanların doğaya karşı gücünün sınırlarını belirlemiştir. Güçlü ile güçsüzün, dost ile düşmanın, uzak ile yakının yan yana yürüdüğü bu krizde, insanlar aralarına sosyal mesafe girse de aynı kaderi yaşıyor olmanın verdiği ortak bir paydada birleştiler. İnsanların nerede ise gönüllü olarak eve kapatıldığ 1 , bu sebeple planlı olmasa da çevre kirliliğinin azaldığı, evden çalışma sistemi ile çalışma koşullarının yeniden tanımlandığı, sektörel ağırlıkların yer değiştirdiği, zenginlik kaynaklarının ne olduğunun tekrar sorgulandığı, nakit paradan dijital paraya geçiş sürecinin fitilinin ateşlendiği bu dönemde dünya yeni bir çağa merhaba dedi.

$\mathrm{Bu}$ salgının, dünya siyasetinde, özellikle sağlık, güvenlik, ticaret, istihdam, tarım, imalat malları üretim ve bilim politikalarında kalıcı bir değişime yol açacağı görülmektedir. Bu yenidünya, daha önce dünya üretimine hâkim olmayan bazı ülkeler için büyük firsatlar sağlayabileceğinden, hükümetler yenidünya düzenine fazla gecikmeden adapte olmak için yeni stratejiler geliştirmelidir (Açıkgöz ve Günay, 2020: 520).

\subsection{Kovid-19 Küresel Krizinin Dünya Ekonomisine Etkileri}

Neo liberal politikalarla şekillenen bir dünyada ekonomi, her zaman ilk öncelik olmakla birlikte birçok gelişmiş ülke liderleri, bu yeniçağda insan sağlığını ekonominin önüne koydu. 26 Mart 2020 tarihinde G-20 liderleri, Kovid-19 üzerine odaklanan olağanüstü bir sağlı zirvesi gerçekleştirdi. Toplantıda şu ana kadar uygulanmakta olan halk sağlığ işlemlerinin ekonomiye olan şiddetli etkileri gerçeğinde, bugüne kadar değişmez olarak bilinen finansal kuralların, hızlı ve ciddi bir şekilde değişime uğradığı kaydedildi (Kickbusch vd., 2020: 1).

Küresel bir sağlık sorunu olmanın yanı sıra Kovid-19'un, dünya ekonomisi üzerinde önemli sonuçları olduğu açıktır. Tüm dünya artık tek bir küresel topluluktur ve bu topluluğun bir kısımda meydana gelen herhangi bir sorun dünyanın geri kalanını da etkilemektedir. Bu gerçekten hareketle uzmanlar, Kovid-19'un küresel gayri safi yurtiçi hâsıla büyümesini, 2020 için bir buçuk puan düşüreceğini tahmin etmektedir (\%2.9'dan \% 2.4'e). Petrol fiyatlarında ve küresel endüstriyel üretimdeki düşüş, küresel borsalarda kısa bir süre içinde $\% 20$ 'den fazla düşüşe neden olmuştur ve 2008 'e benzer küresel durgunluk riski gün geçtikçe büyümektedir (Gupta vd., 2020: 1).

Salgın hastalıkların ekonomi üzerine etkisine yönelik yapılan araştırmalar, daha çok hastalık izni ve hastalığa 
bağlı ölümler nedeniyle işgücü sayısındaki azalmadan kaynaklanan doğrudan etkilerle ilgili olmakla beraber, ekonomi için salgını azaltmaya yönelik önlemler ve tüketici davranışındaki değişiklikler gibi dolaylı etkiler çok daha önemlidir. $\mathrm{Bu}$ etkiler büyük organizasyonların, ticari fuarların iptaline dolayısıyla turist trafiğinde azalmaya neden olmaktadır. Üstelik karantina önlemleri malların üretimini engelleyebilmekte ve sınır ötesi de dâhil olmak üzere üretim süreçlerini ciddi şekilde bozabilmektedir (Gern ve Hauber 2020: 223).

Kriz hem gelişmiş hem de gelişmekte olan ülkeleri aynı anda etkisi altına almıştır. Uluslararası Para Fonu (IMF) ve Birleşmiş Milletler Ticaret ve Kalkınma Konferansı (UNCTAD) tahminine göre, yıllardır sürdürülemez borç yükleriyle mücadele eden gelişmekte olan ülkeler, Covid19 krizinin ardından toparlanmak için en az 2.5 trilyon dolar likidite ve finansman desteğine ihtiyaç duyacaklardır (UNCTAD, 2020: 9).

Tablo 3'de görüldüğü üzere Kovid-19 gelişmiş ekonomileri de en az gelişmekte olanlar kadar etkilemektedir. Ekonomik Kalkınma ve İşbirliği Örgütü (OECD) "Coronavirüs: Dünya Ekonomisi Risk Altında" Ekonomik Görünüm Ara Değerlendirme Raporu'nda dünya genelinde büyüme beklentilerini bir önceki yıl (Kasım 2019) tahminine göre 0.5 düşürerek \% 2.4' e çekmiştir. G20 ülkelerinin de büyüme beklentilerini aynı oranda düşürerek \% 2.7'ye çeken OECD, Avrupa bölgesi büyüme beklentilerini de \% 1.2 'den \% 0.8' e çekmiştir. Covid-19 salgınının ilk başladığı ülke olan ve yaklaşık 1,4 milyar nüfusu, 12,2 trilyon \$ GSYİH (OECD 2019: 8) ile dünyanın büyük ekonomilerinden biri olan Çin de büyüme beklentilerinin aşağıya çekildiği ülkeler arasında yer almaktadır. OECD Çin ekonomisi için büyüme beklentilerini \% 6,1'den \% 4.9'a düşürmüştür (OECD, 2020: 2).

Tablo 3. OECD Ara Değerlendirme Ekonomik Görünüm Tahminleri (2 Mart 2020).Reel GSYIH Büyümesi, yıllık \% değişim

\begin{tabular}{|c|c|c|c|}
\hline Ülkeler & 2019 & $\begin{array}{l}2020 \quad \text { Geçici } \\
\text { Ek.Gör. } \\
\text { verileri/Kasım } \\
\text { EG'den fark1 }\end{array}$ & $\begin{array}{l}2021 \text { Geçici Ek.Gör. } \\
\text { verileri/Kasım EG'den } \\
\text { fark1 }\end{array}$ \\
\hline Dünya $^{1}$ & 2.9 & $2.4 /-0.5$ & $3.3 / 0.3$ \\
\hline $\mathrm{G} 20^{12}$ & 3.1 & $2.7 /-0.5$ & $3.5 / 0.2$ \\
\hline Avustralya & 1.7 & $1.8 /-0.5$ & $2.6 / 0.3$ \\
\hline Kanada & 1.6 & $1.3-0.3$ & $1.9 / 0.2$ \\
\hline Euro Bölge & 1.2 & $0.8 /-0.3$ & $1.2 / 0.0$ \\
\hline -Almanya & 0.6 & $0.3 /-0.1$ & $0.9 / 0.0$ \\
\hline -Fransa & 1.3 & $0.9 /-0.3$ & $1.4 / 0.2$ \\
\hline -İtalya & 0.2 & $0.0 /-0.4$ & $0.5 / 0.0$ \\
\hline Japonya & 0.7 & $0.2 /-0.4$ & $0.7 / 0.0$ \\
\hline Kore & 2.0 & $2.0 /-0.3$ & $2.3 / 0.0$ \\
\hline Meksika & -0.1 & $0.7 /-0.5$ & $1.4 /-0.2$ \\
\hline Türkiye & 0.9 & $2.7 /-0.3$ & $3.3 / 0.1$ \\
\hline B.Krallik & 1.4 & $0.8 /-0.2$ & $0.8 /-0.4$ \\
\hline $\mathrm{ABD}$ & 2.3 & $1.9 /-0.1$ & $2.1 / 0.1$ \\
\hline Arjantin & -2.7 & $-2.0 /-0.3$ & $0.7 / 0.0$ \\
\hline Brezilya & 1.1 & $1.7 / 0.0$ & $1.8 / 0.0$ \\
\hline Çin & 6.1 & $4.9 /-0.8$ & $6.4 / 0.9$ \\
\hline Hindistan $^{3}$ & 4.9 & $5.1 /-1.1$ & $5.6 /-0.8$ \\
\hline Endonezya & 5.0 & $4.8 /-0.2$ & $5.1 / 0.0$ \\
\hline
\end{tabular}

\begin{tabular}{llrc} 
Rusya & 1.0 & $1.2 /-0.4$ & $1.3 /-0.1$ \\
S.Arabistan & 0.0 & $1.4 / 0.0$ & $1.9 / 0.5$ \\
G.Afrika & 0.3 & $0.6 /-0.6$ & $1.0 /-0.3$ \\
\hline
\end{tabular}

1. Satın alma gücü paritesinde hareketli nominal GDP ağırlıkları kullanılarak hesaplanan toplam

2. Avrupa Birliği G20 tam üyesidir, fakat G20 toplamı sadece aynı zamanda kendisi üye olan ülkeleri kapsamaktadır.

\section{Nisan ayından başlayan mali yıl}

(Kaynak: Interim Economic Assessment Coronavirus: The World Economy at Risk 2 March 2020 s:2)

Küresel krizin gelişmiş ve gelişmekte olan ülkeler üzerinde yıkıcı bir etkisi de dünya seyahatine yönelik getirilen katı engellerdir. $\mathrm{Bu}$ seyahat kisitlamaları hemen hemen tüm sektörler üzerinde zorlu bir süreci beraberinde getirirken özellikle turizm sektörü ve hava taşımacılığı üzerindeki etkileri oldukça yıkıcı olmuştur. Birleşmiş Milletler Dünya Turizm Örgütü (UNWTO), “Kovid-19 İlgili Seyahat Kısıtlamaları Turizm İçin Küresel Bir İnceleme" raporunda dünya çapında uygulanan seyahat kısıtlama oranlarını ve uygulama şekillerini açıkladı. Grafik 2'den görüleceği gibi Ortadoğu (\%54) ve Afrika (\% 45) daha çok uçuşları askıya alırken, Amerika kıtası (\% 51), Avrupa (\% 48), Asya ve Pasifik ( $\%$ 46) toplam veya kısmi olarak sinırları kapatmıştır. Avrupa (\% 28) ve Asya-Pasifik (\% 24) belirli ülkelere yönelik seyahat kısitlamasına en fazla giden bölgeler olmuştur (UNWTO, 2020: 8).

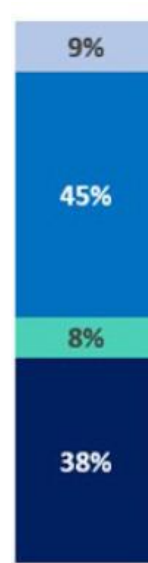

Africa

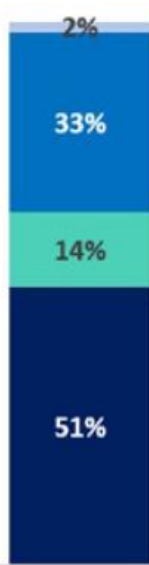

Americas

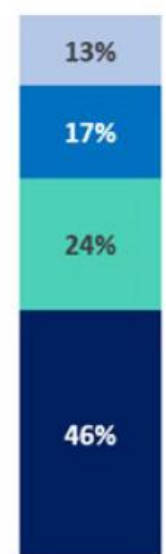

Asia and the Pacific
Farklı önlemler Uçuşların askıya alınması Belirli bir ülkeye yönelik varış yerine özgü seyahat kısıtlaması Toplam / kısmi sınır kapanışı

Grafik 2. Seyahat Kısıtlamalarının Bölgesel Dağılımı (20 Nisan 2020 itibariyle)

(Kaynak: UNWTO (2020) COVID - 19 Related Travel

Restrictions A Global Rewiev for Tourism Second Report as of 28 April 2020: 8)

UNWTO raporuna göre 20 Nisan 2020 itibariyle 217 destinasyonda dört geniş seyahat kısıtlaması uygulanmaktadır. Grafik 3'de görüldüğü üzere 97 destinasyon (\% 45) tamamen veya kismen turistlere sınırlarını kapatmış durumdadır ve 65 ülkede (\% 30) 
uçuşlar tamamen veya kısmen askıya alınmıştır. 39 ülke ise (\%18) belirli ülkelere karşı sınırlarını yolcu girişine kapatmıştır. Kalan 16 varış noktası ise karantina, kendi kendine izolasyon, vize tedbirleri gibi farklı önlemler uygulamaktadır (UNWTO, 2020: 7).

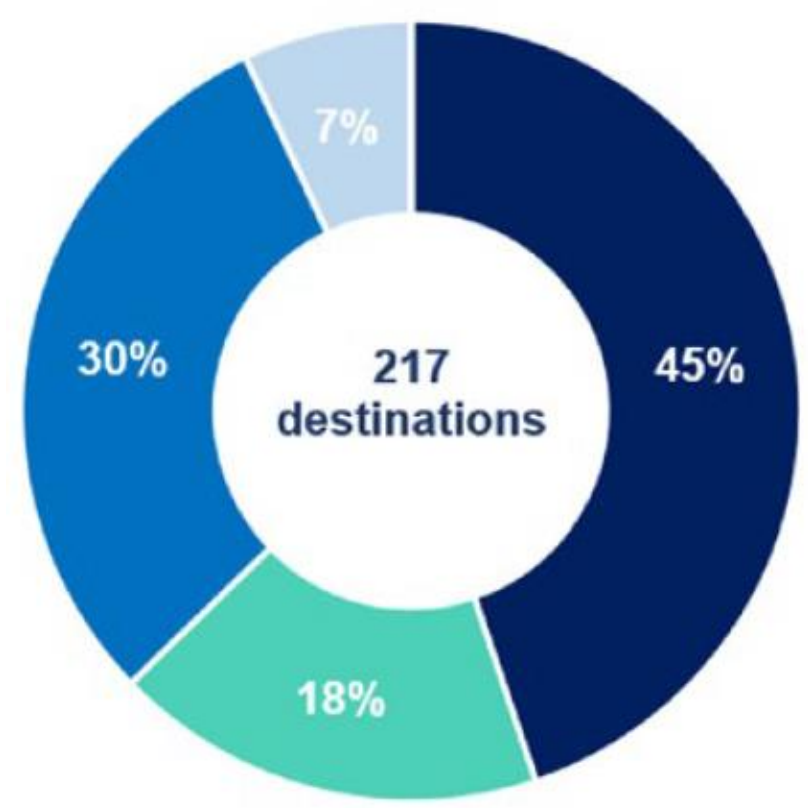

Sinırların tamamen veya kısmen kapanmas Hedefe özgü seyahat kısıtlaması

\%18 Tüm veya kısmi seferlerin askıya alınması Farklı önlemler

Not: Farklı önlemler şunları içerir: Vizenin geçersiz kılınması, ülke içinde bir bölgeye seyahat kısıtlaması getirilmesi, karantina veya kendi kendine izolasyon gereksinimi ve uyruğa yönelik kisitlamalar.

Grafik 3. Hedeflerine göre COVID-19 seyahat kısıtlamaları

(Kaynak: UNWTO (2020) COVID - 19 Related Travel

Restrictions A Global Rewiev for Tourism Second Report as of 28 April 2020: 7)

Seyahat kısıtlamaları diş ticaretten üretim endüstrisine kadar tüm ekonomiyi derinden etkilerken en çok etki ettiği sektörlerden biri de küresel GSYİH'nin \% 10,3'ünü temsil eden ve dünyada her 10 kişiden birinin istihdamını sağlayan turizm sektörüdür. WTTC'nin yaptığı son araştırmaya göre 2020 yılında turizm sektöründeki 100,8 milyon kişinin işini kaybedeceği öngörülmektedir. Araştırmaya göre, 2020 yılında tahmini olarak GSYİH kaybı 2,7 trilyon ABD doları olacaktır. Coronavirus salgınının süpürme etkisiyle Asya-Pasifik bölgesi 63,4 milyon iş kaybı ve GSYIH'den 1,041 milyar ABD doları zararla krizden en fazla etkilenen bölge olacağı öngörülmektedir. Amerika'nın Seyahat ve Turizm GSYİH'sinde 14.1 milyon iş kaybı ve 791 milyar ABD doları gelir kaybı yaşanması beklenmektedir. Raporda Avrupa'da seyahat ve turizm endüstrisinde 13 milyon iş kaybı ve seyahat ve turizm GSYİH'sında ise 709 milyar ABD doları kayıp beklendiği yer almaktadır (WTTC, 2020).
Uluslararası Hava Taşımacılığı Birliği’nin (IATA) küresel kriz raporuna göre, Kovid-19 salgınının havayolu taşımacılığında yol açtığı kriz nedeniyle, 25 milyon kişi işini kaybetme riski ile karşı karşıyadır. Dünya genelinde yaklaşık 65,5 milyon insan seyahat ve turizm sektörleri de dâhil olmak üzere havacılık endüstrisinden geçimini sağlamaktadır. Bunların içinde 2.7 milyon kişi havayollarında çalışmaktadır ve seyahat kısıtlamalarının üç ay sürmesi halinde, havacılık ve ilgili sektörlerde 25 milyon kişinin işsiz kalması söz konusudur. Buna göre; Asya Pasifik'te 11,2 milyon, Avrupa'da 5.6 milyon, Latin Amerika'da 2,9 milyon, Kuzey Amerika'da 2.0 milyon, Afrika'da 2.0 milyon ve Orta Doğu'da 0.9 milyon kişi işini kaybetme tehlikesi ile karşı karşıyadır (IATA, 2020). Seyahat kisitlamalarının krizden etkilenen havayolu şirketlerinin çökmesinin de etkisiyle havayolu endüstrisine maliyetinin 252 milyar \$ olması beklenmektedir (Pierce, 2020: 1).

Uluslararası Çalışma Örgütü’nün (ILO) yayınladığı rapora göre, Kovid-19 salgınını nedeniyle dünyada yaşanan işgücü kayıplarının bu hızla sürmesi halinde küresel işgücünün yaklaşık yarısını oluşturan 2 milyar kayıt dışı işçinin yaklaşık 1,6 milyarı zarar görecektir. Raporda kriz öncesi döneme (2019 dördüncü çeyreği) göre \%10, 5 oranında kötüye gidiş öngörülmekte ve bu oran 305 milyon tam zamanlı iş kaybı anlamına gelmektedir. Salgının uzun sürmesi nedeniyle durumun daha da kötüleşeceği ve ikinci çeyrekte çalışma süresi kaybının Amerika kıtasında \%12,4, Avrupa ve Orta Asya'da \%11.8, diğer bölgelerde, en düşüğü \% 9.5'in üstünde olmak üzere devam edeceği kaydedilmektedir. Dünya genelinde 436 milyonu aşkın işletme işlerin durması tehdidi ile karşı karşıyadır. Bu işletmelerin 232 milyonu toptan ve perakende ticarette, 111 milyonu imalatta, 51 milyonu konaklama ve yiyecek hizmetlerinde, 42 milyonu gayrimenkul ve diğer iş kollarında faaliyet göstermektedir (ILO, 2020).

Kovid-19'un finansal piyasalar ve sermeye piyasalarına etkisi de çok sert olmuştur. Rusya, Asya, Avrupa ve ABD piyasalarında sert düşüşler yaşanırken Dow Jones sanayi endeksi tarihinde üçüncü kez bin puanın üzerinde bir düşüş kaydetmiştir. Avrupa ve Asya Borsalarındaki düşüşü Rusya borsası izlemiştir. Küresel ekonominin Coronavirus salgınından hasar görmesi ve şirket kârlarının düşmesi, güvenli liman niteliğindeki doların yükselmesine neden olmuştur. Asya hisse senetleri mayıs ayına düşüşle başlamış, Japonya'nın Nikkei 225 Endeksi, yüzde 2.3 gerileyerek 19,730.41 puanda seyretmiştir. S\&P/ASX 200 Endeksi yüzde 3.9 azalışla 5,308.90 seviyesinde gerçekleşmiştir. Küresel piyasalarda yaşanan risk iştahındaki düşüş hisse senetlerinde satıcılı bir seyre neden olmuştur. Altın fiyatları Coronavirus'e ilişkin temkinli iyimserliğin artması ile son 7 haftanın (01.05.2020) en büyük kaybını yaşamıştır (Bloomberg, 2020).

Çin finansal piyasalarında Coronavirus sebebiyle Şangay Borsası'nda işlem gören hisselerin toplam değeri bir günde 393 milyar dolar düşmüştür. Borsada işlem gören şirketlerin dörtte üçünden fazlası \% 10'luk değer kayıpları yaşarken Şenzen ve Şanghay Borsalarının toplam piyasa 
değeri 7,8 trilyon dolar düzeyinde gerçekleşmiştir (Ulusoy, 2020).

Tahvil piyasasında ise Coronovirus sonrası yatırımcılar görece güvenli gelişmiş ülke tahvillerine yönelmiştir. ABD’nin 10 yıllık Hazine tahvili \%0,69 ile çok düşük bir seviyeye gerilemiştir. İsviçre'de 10 yıllık tahvil faizi yüzde -0,94'e düşmüş ve Türkiye tahvil faizleri, \%11 ile en yüksek seviyeye gelmiştir (Investaz, 2020).

Krizin petrol fiyatları üzerindeki etkisine gelince, Kovid-19 nedeniyle petrol talebinin azaldığını ve petrol piyasasında yüksek miktarda arz fazlasina neden olduğunu görülmektedir. Petrol talebi krizde, V şeklinde bir rota izlemiştir, Nisan 2020 'de düşük bir noktaya ulaşan petrol talebinin, 2021'e kadar aşağı yönlü riskler içereceği düşünülmektedir. 2020 için ortalama talebin 2019'a göre \% 10,8 düşmesi beklenmektedir. Nisan ayında, y1llık bazda $\% 33,5$ 'lik bir düşüşle ve 2020 'de bir bütün olarak \% 12,4'lük bir talep düşüşü ile Avrupa'nın, talebin en fazla düşeceği bölge olacağı tahmin edilmektedir (Rystad Energy, 2020: 12).

\subsection{Kovid-19 Küresel Kriziyle Mücadelede Alınan Önlemler}

Piyasaları sakinleştirmek ve harcamaları teşvik etmek için, birçok ülkedeki merkez bankaları, finansal piyasalarda borçlanmayı daha ucuz hale getirmekte ve piyasaya likidite enjekte etmektedir. Hükümetler ücret sübvansiyonları, düşük gelirli hane halklarına nakit yardımı, işletmeler için vergi ve kira indirimlerini içeren ekonomik destek paketleri açıklamaktadır. Ayrıca, Uluslararası Para Fonu (IMF) ve Dünya Bankası, zor durumda olan ülkelere yardım etmek için sırasıyla 50 milyar dolar ve 14 milyar dolarlık finansman paketleri açıklamıştır. Buna ek olarak, ABD 2.2 trilyon dolarlık bir kurtarma paketini senatodan geçermiştir. Birleşik Krallık (İngiltere), iflasları, büyük işten çıkarmaları ve salgın nedeniyle çalışamayanlar için çalışan ücretlerinin \% 80'ine kadar ödeme yapma kararı almıştır (Açıkgöz ve Günay, 2020: 523).

Gelişmiş ülkelerin politikacıları, vatandaşlara ve işletmelere benzeri görülmemiş miktarda destek sözü vererek hızlı bir şekilde krize yanıt vermişlerdir. Uluslararası Para Fonu ve Dünya Bankası, Kovid-19 yükü ile karşı karşıya kalacak düşük ve orta gelirli ülkeleri desteklemek için bir dizi araç duyursa da (örneğin IMF'nin, krizden etkilenen ülkelere 1 trilyon dolara kadar kaynak ayırdığını duyurduğu krediler) bu destekler dağıtılmadan önce uygulanması gereken reformlar gibi tartışmalı koşullara bağlıdır. Bunun yanı sıra IMF ve Dünya Bankası, mali hedeflere ve piyasa odaklı çözümlere, sağlık sorununa yönelik ayırdıkları kaynaktan daha fazlasını ayırdılar. Sağlık sorunlarına ayırdıkları kaynak, 1 trilyon dolarlık kaynağın sadece 6 milyar dolarıdır (Kentikelenis vd., 2020: 1-2).

Her ülke krize karşı kendi önlemlerini alırken G20 ülkelerini oluşturan dünyanın en büyük 19 ekonomisi ve $\mathrm{AB}$, Coronavirus ile mücadelede 5 trilyon dolar değerinde mali önlemler bütçesi ile beraber hareket etme kararı almıştır. G20 ülkeleri, Afrika ülkelerinin de aralarında olduğu gelişmekte olan ülkelerle krizden olumsuz etkilenen ülkelere destek vereceğini açıklamıştır (Ünveren, 2020).
Kovid-19, insanlığa yaşamlarının birbirlerine bağl1-bağımlı olduğunu, eşitsizlik veya çevresel bozulmaya karşı birlikte hareket etmek zorunda olduklarını göstermiştir. Kovid-19 ayrıca bilime olan inancı da arttırmıştır. Fakat bu kriz, kitle iletişim araçlarının desteğini arkasına alan popülist politikacılara, toplumu, genç-yaşlı, zengin-fakir, hastasağlıklı, etnik azınlıklar-çoğunluklar olarak bölmek sınıflandırmak için firsat da vermiştir (McKee ve Stuckler, 2020: 3). Dolayısıyla Kovid-19 virüsünün yol açtığı küresel krizin sonuçlarının nasıl olacağı, bilimin mi politikacıların mı üstün geleceğine, insanlığın hangi tarafta duracağına bağlıdır.

\subsection{Yeni Coronavirus'un Türkiye Ekonomisine Etkileri}

Türkiye'de ilk Kovid-19 vakası 11 Mart 2020 tarihinde tespit edilmiştir. İlk tespit edilmesinden sonra hızlı bir artış göstermiş ve vaka sayısı 30 Mayıs 2020 tarihinde 163.103 kişiye ulaşmıştır. 30 Mayıs itibariyle 4515 kişinin vefat ettiği ülkede iyileşen hasta sayısı ise 126.984'e ulaşmıştır (Sağlık Bakanlığı, 2020). En çok İstanbul, İzmir, Ankara, Kocaeli ve Konya'da görülen hastalık ülke geneline kısa sürede yayılmıştır. Türk hükümeti ilk vakanın görüldüğü günden itibaren bilim kurulu tavsiyelerini de dikkate alarak bir dizi önlem almıştır. İlk etapta 31 daha sonra azaltılarak 24 şehre giriş çıkışlar kontrollü hale getirilmiştir. Hükümet, yaşı 65 ve üstü ile 20 ve altı kişilere sokağa çıkmayı yasaklamıştır. Özellikle resmi tatiller başta olmak üzere belirli gün ve hafta sonları dışarı çıkma yasağı uygulamaları, virüs salgınını kontrol etme yolunda önemli adımlar olmuştur.

Krizin Türkiye ekonomisine etkileri hızla artmaktadır. 2001 krizinin etkilerini atlatamadan 2008 krizine yakalanan Türkiye, bu krizin etkilerini atlatamadan bu kez Kovid-19 küresel krizine maruz kalmıştır. Enflasyon ve işsizlik sorunları ile mücadele eden Türkiye, krizden en ağır etkilenen sektörlerden olan turizm ve ulaştırma sektörüne olan bağımlılığı nedeniyle de krizin etkilerini derinden hissetmektedir.

Türkiye 2016 yılında yaşanan 15 Temmuz darbe girişiminin yarattığı belirsizlik ortamında ciddi üretim kayıpları yaşamış, 2017 yılında toparlanma sürecine adım attığı anda ise 2018 yılının ikinci yarısında döviz krizi ile yüzleşmiş ve yüksek enflasyonun etkisi altına girmiştir. Türkiye Cumhuriyet Merkez Bankası (TCMB) 2019 yılı son çeyreğinde enflasyonu kontrol altına alabilmek için faiz oranında ardı ardına indirimlere gitmiş ve piyasayı canlandırmaya yolunda adımlar atmıştır. Bu çabalar Türkiye ekonomisini toparlamaya yetmemiş ve 2017 yılında GSYİH büyümesi 7,4'ten 2018'de 2,6'ya gerilemiş ve 2019'da 0,9 olarak gerçekleşmiştir. Tablo 4'de Türkiye'nin 2020 yılı öncesindeki ekonomik durumunu yansıtan üç yıllık veriler özetlenmiştir (Eryüzlü, 2020). 
Tablo 4. Türkiye Göstergeleri

$\begin{array}{llll}\text { Yıllar } & 2017 & 2018 & 2019 \\ \text { GSYİH Büyüme } & 7,4 & 2,6 & 0,9 \\ \text { Toplam Tüketim Büyümesi } & 5,9 & 1,2 & 0,9 \\ \text { Toplam Yatırımların Büyümesi } & 7,8 & -0,6 & -10,0 \\ \text { Dış Ticaret Dengesi (milyar \$) } & -74,2 & -54,3 & -29,2\end{array}$

Kaynak: Eryüzlü, 2020:11.

Son birkaç yıl içerisinde hem reel sektörde hem finans sektöründe ekonomik kırılganlıkları artan, sayısı 3.5 milyonu aşan Suriyeli mülteci göçü nedeniyle zor bir süreç yaşayan Türkiye, artan enflasyon ve işsizlik oranları, daralan yatırımların zorlayıcı etkisi ile Kovid-19 krizini aşmak için çabalamaktadır. Dünya Bankası verileriyle (20 Nisan 2020), 754 milyar \$ GSYİH, 9 bin dolar kişi başına milli geliri ile yaklaşık 83 milyonluk nüfusa sahip Türkiye, Kovid-19 salgının büyüme ve hanehalkı gelir seviyeleri üzerindeki yıkıcı etkisi ile karşı karşıyadır. Dünya Bankasına göre dünya ticaretinde yaşanan kesintiler, sermayenin daha güvenli yerlere hareketi ve risk primlerinin hızla yükselmesi, aynı konumda olan her ülke gibi Türkiye'yi de etkileyecektir. $\mathrm{Bu}$ etkilenme bazen ihracat ve ithalatta, bazen turizm gibi öncelikli sektörlerde, bazen finansmana ulaşmakta, bazen enflasyonda ve çoğu zaman da kur istikrarında yaşanacaktır. Dünya Bankası tahminlerine göre büyüme oranı, Kovid-19 öncesindeki tahmine göre, 2020 yılı için 3 puandan fazla düşerek yüzde 0,5 olacaktır. Özellikle turizm ve ulaştırma sektörünün en ağır etkilendiği ülkelerden biri olarak Türkiye'de, 2020 yılında ihracat azalma sürecine girerek ülkenin cari açığının artmasına yol açacaktır. Yoksulluk oranına ilişkin tahminler, bu oranın önümüzdeki aylarda, işgücü gelirlerindeki düşmeye bağlı olarak, yükseleceği ve nüfusun yüzde 9'unu bulacağını öngörmektedir (Dünya Bankası, 2020).

Yıllardır mücadele ettiği dış ticaret açı̆̆ı nedeniyle izlediği ekonomi politikalarının merkezine ihracatı arttırıp ithalatı azaltmayı koyan Türkiye, Kovid-19 salgını nedeniyle dış ticaret açığını kapatma hedeflerini ertelemek zorunda kalmıştır. Ticaret Bakanlığı işbirliğiyle Türkiye İstatistik Kurumu tarafindan oluşturulan ve geçici olan diş ticaret verilerine göre, ihracat 2020 yılı Mart ayında, 2019 yılının aynı ayına göre \%17,8 azalmış ve 13 milyar 422 milyon dolar olarak gerçekleşmiştir. Aynı verilere göre ithalat, \%3,1 artmıs ve 18 milyar 813 milyon dolar olarak gerçekleşmiştir. İhracat 2020 yılı Ocak-Mart döneminde bir önceki yılın aynı dönemine göre \% 4,0 azalmış ve 42 milyar 749 milyon dolar olarak gerçekleşmiş; ithalat ise \%10,3'lük artışla 55 milyar 655 milyon dolar olmuştur. Dış ticaret açığı Mart ayında \%181,6 artarak 1 milyar 915 milyon dolardan 5 milyar 391 milyon dolara yükselmiştir. İhracatın ithalatı karşılama oranı ise 2019 Mart ayında \%89,5 iken, 2020 Mart ayında \%71,3'e gerilemiştir (TÜİK, 2020).

TÜİK verilerine göre, Mart ayında en çok ihracat yapılan ülke Almanya olurken, onu sırasıyla ABD, Birleşik Krallık, İspanya ile İtalya izlemiştir. Bu ülkelere yapılan ihracat, toplam ihracatın yaklaşık \%30’unu oluşturmuştur. İthalat rakamlarında ise Almanya yine ilk sırada yer alırken onu sırasıyla Çin, ABD, ile Rusya Federasyonu ile İsviçre takip etmiştir. İlk 5 ülkeden yapılan ithalat, toplamı ithalatın \%38'ini oluşturmuştur (TÜİK, 2020).

Türkiye'de ekonomi politikası yapanların Kovid-19'un yol açtığı küresel ekonomik krizle mücadele ederken elini zayıflatan iki önemli sorun enflasyon ve işsizliktir. Uzun yıllar enflasyonu iki haneli rakamları altına düşürmek ve işsizlik sorununu çözmek için çabalayan politika yapıcılar, Kovid-19 krizi ile her geçen gün kötüleşen bir tablo ile kar karşıya kaldılar.

Türkiye'nin uzun yıllardır mücadele ettiği enflasyon canavar1, Kovid-19 ile daha da güçlenmiştir. TÜíK verilerine göre, TÜFE'de $(2003=100) 2020$ yılının Nisan ayında, aynı yılın bir önceki ayına göre \% 0,85, bir önceki yılın Aralık ayına göre ise \% 3,16, bir önceki yılın aynı ayına göre ise \% 10,94 olarak gerçekleşmiştir. 12 aylık ortalamalara göre ise \% 12,66 artış gerçekleştiği görülmektedir. Artışın en yüksek olduğu grup \% 31,32 ile alkollü içecekler ve tütün olurken diğerleri \% 20,34 ile çeşitli mal ve hizmetler ve \% 14,52 ile konut olmuştur. Artışın en düşük olduğu ana grup \% 4,90 ile giyim ve ayakkabı olurken onu sırasıyla \% 4,91 ile eğlence ve kültür; \% 5,54 ile ulaştırma izlemiştir (TÜİK, 2020). Türkiye piyasalarında yaşanan daralmaya rağmen enflasyonun artmaya devam ettiği görülmektedir.

Avrupa Birliği Komisyonu 2020 Yılı Bahar Ekonomik Görünüm Raporu'na göre salgının fiyatlar üzerinde aşağı yönlü baskısı, talep düşüşü, enerji fiyatlarındaki sert düşüş, firmaların aktivitelerindeki düşüş ve işgücü piyasasındaki kötüye gidiş çekirdek enflasyonu, Euro bölgesinde bu yıl \% 0.2 'ye geriletmiştir. 2021 yılında ise enerji fiyatlarında yaşanacak gelişmelere bağlı olarak çekirdek enflasyonun \% 1.1 olacağı öngörülmektedir. Komisyon raporunda Türkiye'de Tüketici Fiyat Endeksinin 2020 yılı için \%11.4 olarak gerçekleşme beklentisi yer alırken 2021 için \%11,7 olarak gerçekleşmesi öngörülmektedir (European Economic Forecast Spring, 2020: 1-5-147). Türkiye'nin piyasalardaki daralmaya rağmen enflasyon ile mücadelesini kesintisiz ve artan oranda sürdürmeye devam edeceği anlaşılmaktadır.

Türkiye'nin işsizlik rakamlarında en dikkat çeken nokta genç işsizlik oranının \% 24.5 olarak gerçekleşmesidir. TÜİK verilerine göre Mart 2020 itibariyle Türkiye'de genel işsizlik oranı \% 13,8'dir. Avrupa Birliği Komisyonu 2020 Yılı Bahar Ekonomik Görünüm Raporu'nda Euro bölgesinde bu yıl için çalışma saatlerindeki keskin düşüş, işini kaybedenler ve genç işsizlerin etkisiyle işsizliğin artacağ1 ve \%9,6 oranında gerçekleşeceğini 2021 yılında ise işsizliğin \% 8.6 oranında olacağını öngörülmektedir. Komisyon raporuna göre Türkiye'de 2020 yılı için işsizlik oranı \%16,9 olarak öngörülürken 2021 yılı için bu oranının düşmeyeceği ve yine 16.9 olarak gerçekleşeceği beklenmektedir (European Economic Forecast Spring, 2020: 1-5- 147).

2.5. Yeni Coronavirus'e Karşı Türkiye'nin Aldığı Önlemler ve Çözüm Arayışları: Kovid-19 Krizi ile mücadelede Türk hükümeti, 18 Mart 2020 tarihinde 15.4 milyar dolarlık ekonomik teşvik paketini açıklamış ve vergi indirimleri, ödeme ertelemeleri ve artan emekli maaşları ile vatandaşlara ve işletmelere yardımcı olmak için çeşitli uygulamalar hayata geçirmiştir (Açıkgöz ve Günay 
2020:524). Ekonomi kurmayları ayrıca likiditeyi artırmak ve uygun kredi koşulları sağlamak için bir dizi önlem almıştır (European Economic Forecast Spring, 2020: 147).

Türkiye'nin bugüne kadar uyguladığı politikalar genelde diğer ülkelerde uygulananlarla benzerlik göstermektedir. Dünyada olduğu gibi Türkiye'de de hane halkları, iş dünyası ve finansal kesimine yönelik tedbirler uygulanmaktadır. Hanehalkının tüketim harcamalarını canlı tutmak için kamu ve özel sektör borçlarının ertelenmesi, karşılıksız gelir destekleri ve işsizlik sigortası gibi ödeneklerle krizin etkileri azaltılmaya çalışılmaktadır. İş âlemine yönelik tedbirlerle de üretimde ve istihdam alanında yaşanabilecek kayıpları azaltmak amaçlanmakta ve bu kapsamda şirket borçlarının ertelenmesi ve yapılandırılması gibi tedbirler alınmaktadır. Yarı zamanlı istihdam ödeneklerine ve ücretli izin ödeneklerine devletin yaptığı destekler iş dünyasına verilen destekler arasındadır. Finansal kesime yönelik desteklerde kamu bankaları kanalıyla, kredi kolaylıkları ve mali kesimin likidite ihtiyacını dikkate alan çalışmalar yapmak önem taşımaktadır (Bayar vd., 2020: 17-18).

Kovid-19 salgınının aynı anda hem arz, hem de talep yönlü bir şok olması uygun önlemler bulmayı zorlaştırmaktadır. Ayrıca talep daralmasının insanların ekonomik durumundan daha çok evlerinden çıkamamaları nedeniyle yaşanması, sorunun çözümüne yönelik yaklaşımları tartışmaya açmaktadır. Talebi arttırmak için fiyat indirimlerine gidilmesi, vergi indirimleri uygulanması gibi geçmişte yaşanan bazı ekonomik durgunluk ve kriz dönemlerinde işe yarayan geleneksel önlemlerin bugün de uygulanıyor olması bu kapsamda değerlendirilebilir. $\mathrm{Bu}$ bağlamda 18 Mart'ta açıklanan Coronavirus krizine karşı yayınlanan önlem paketindeki havayolu ve konaklama sektörlerine sağlanan vergi indirimlerinin de talepte ciddi bir canlanma yaratması ve istihdamı koruyucu bir etki yapmasını beklemenin ne derece gerçekçi olduğu tartışmalıdır. İş dünyasına yönelik uygulamalar için de aynı durum geçerlidir. Vergi ve kredi borçlarının ertelenmesi ve yeni kredi kolaylıkları sağlanması geçici bir rahatlama sağlasa da talep canlanmadığı sürece iş dünyasının sorunlarını kalıcı olarak çözmeyeceği açıktır. İstidama yönelik alınan önlemler, hanehalklarına sağlanacak nakit gelir destekleri ve borç ertelemeleri gibi önlemler doğru adımlar olmakla beraber tedbirleri genişletmek ve özellikle istihdama yönelik ilave tedbirler almak gerekmektedir (Aşık ve Sayan, 2020: 2-3-8).

Yaşanan küresel belirsizlik ortamında Türkiye'de bir yandan döviz talebi artarken diğer yandan döviz arzı düşmektedir. $\mathrm{Bu}$ bağlamda önem arz eden döviz kuruna yönelik gelişmeleri dikkatle takip etmektir. Özatay ve Sak, kurdaki gidişatı hızla tersine çevirmenin mümkün olduğunu ve ülkenin diş borcunu rahatlıkla ödeyecek kapasitesinin olduğunu göstermenin önemli olduğunu savunmaktadır. Özatay ve Sak, birincisi uluslararası kuruluşlardan geçici döviz likiditesi temin etmeye yönelik anlaşma imzalanması, ikincisi borç ödemelerini erteleyecek bir mekanizma geliştirilmesi yolunda adımlar atılması olmak üzere Türkiye'nin önünde iki seçenek olduğunu belirtmektedir (Özatay ve Sak, 2020: 3-4).

Kriz belirsizliğini korumaya devam ederken ülkeler de adım adım normalleşme sürecine girme yolunda çaba sarf etmektedir. Her ülke vaka sayısı, ölüm oranı ve ekonomik ve sosyal koşullarını göz önüne alarak farklı bir takım planlamalarla kendi takvimlerine göre normalleşme sürecine adım atmaktadır. Türkiye'de de normalleşme yolunda adımlar atılmaya başlanmıştır. Dört aşamalı uygulanan planın birinci aşaması 11 Mayıs, ikinci aşaması 27 Mayıs-31 Ağustos, üçüncü aşaması1 Eylül-31 Aralık, dördüncü aşaması ise 1 Ocak ve sonrası olarak planlanmıştır. İlk aşamada kuaförler, güzellik merkezleri ve alışveriş merkezleri kontrollü olarak açılmıştır.

\section{Sonuç ve Öneriler}

Dünya benzeri görülmemiş bir krizle mücadele etmektedir. Tüm dünyayı aynı şiddette olmasa da aynı anda etkisine alan bu kriz, sadece yaşam ile ölüm arasındaki mücadeleyi değil, sağ kalanların nasıl bir dünyaya uyanacaklarını ve bu dünyada var olma mücadelesini de tarihe not olarak düşecektir. Bu mücadelenin tartışmasız en önemli aktörleri sadece gelişmiş ülkelerin değil gelişmekte olan ülkelerin insanları ve bu krizle mücadele etmek için gecelerini gündüzlerine katan hükümetler, uluslarüstü kuruluşlar ile sağlık ve ekonominin aktörleri başta olmak üzere bilim insanlaridir.

$\mathrm{Bu}$ krizden kurtulmak için tüm bu aktörlerin üzerine düşen görevler farklıdır. Hükümetler, ülkenin en etkili ve yetkin organıdır. Hükümetler, yasama, yürütme ve yarg1 organlarının krize karşı uyumlu şekilde çalışmasını organize etmekle yükümlüdür. Hükümet, bakanlıkları aracılığıyla ülkenin sağlık politikasından ekonomisine, eğitim politikasından dış politikasına kadar her alandaki düzenlemelerini titizlikle yerine getirmekle sorumludur. Dolayısıyla Türkiye'nin Kovid-19 virüsünün yol açtığı Küresel Ekonomik krizden en az hasarla çıkabilmesinin en önemli koşulu etkin ve etkili bir hükümet politikasıdır. Hükümet destek paketleri ile krizden en çok etkilenen kesimleri gözetmeli, sadece sektörel bazda destekler, vergi indirimleri ve borç ötelemeleri ile yetinmemeli özellikle alt gelir grubuna yönelik kesimin gelirini güvence altına almalidir.

Krizin ikinci önemli aktörü bilim adamlarıdır. Hükümetin, etkin ve etkili bir program uygulaması için, Türkiye'nin sağlık, fen ve sosyal bilimler alanında yetkin bilim adamlarının öngörülerine, bilgilerine ve multidisipliner çalışmalarına ihtiyacı vardır. Hükümetin önünü açtığı ve desteklediği bilim adamlarının özellikle aşı geliştirilmesi, hastaların doğru tedavi protokolü ile tedavi edilmesi, toplumun bu süreci psikolojik ve sosyal açıdan en az zararla atlatması, çocuk, ergen ve gençlerin sağlik nedeniyle yaşanan izolasyon ve yeni eğitim sistemindeki belirsizliğin etkilerinden en az hasarla çıkması yolunda hızlı bilimsel çalışmalar hayata geçirilmelidir.

Krizin üçüncü önemli aktörü krizi bizzat yaşayan ve krizin yükünü sırtlayan iş dünyasıdır. Finans sektöründen sanayisine, tarım sektöründen hizmet sektörüne ülkenin üretimini sırtlayan bu kesim, varlıkta da yoklukta da Türkiye'nin geleceğine yatırım yapmalı, kısa vadeli çıkarlarının yerine uzun vadeli ve sürdürülebilir hedeflerini koymalıdır. Şirketlerin en büyük hedefinin kar maksimizasyonu olması kapitalist dünyada bir realite olmakla beraber diğer bir realitenin krizlerle güçlenmek 
olduğundan hareketle karlılıklarından ödün verme pahasına istihdama desteğini çekmemelidir. İş dünyası ayrıca çalışanlarının bu dönemde yaşadığı maddi ve manevi zorluklara karşı bir duruş sergileyerek sosyal projelere ağırlık vermeli ve gençlerin eğitimine destek olma yolunda gerek hükümetle gerekse sivil toplum kuruluşlarıyla omuz omuza çalışmalıdır.

Krizin dördüncü ve belki de en önemli aktörü Türkiye Cumhuriyeti vatandaşlarıdır. Salgınla mücadelede hükümetin aldığı tedbirlere harfiyen uyarak normalleşme sürecine en büyük katkıyı verecek olan güç, Türk halkıdır. Salgın ne kadar çabuk kontrol altına alınırsa ülke o kadar çabuk normalleşme sürecine girecektir. $\mathrm{Bu}$ gerçekten hareketle kurallara titizlikle uymalı, kendi sağlığını koruma yolunda attığı adımlarla toplum sağlığını da koruyacağı bilinci ile hareket etmelidir. Dünyanın hıla tüketim toplumu olma yolunda ilerlediği çağımızda salgın vesilesi ile tüketimi kısarak bu gidişe dur demeli ve uzun vadede ülke kaynaklarını verimli kullanıp çevreyi korumak ve gelecek nesillere daha iyi bir dünya birakma yolunda cesur adımlar atmalıdır.

Türkiye krizin bazı firsatlar içerdiğini de unutmamalıdır. Suriyeli mültecilere kapılarını açan ve zor durumda olanların sığındığı bir ülke olan Türkiye, barışçıl tutumunu salgın sırasında tüm ülkelere yardım yollayarak bir kez daha vurgulamıştır. Bu kriz Türkiye'nin dış ülkelerle son yıllarda bozulan dış ilişkilerini düzenlemekte önemli bir firsattır.

Bununla birlikte, krizin Türkiye'ye sunduğu diğer bir firsat azalan enerji faturaları olacaktır. Petrol fiyatlarının düşmesinin enerji ithalatçısı bir ülke olan Türkiye açısından önemli bir firsat olduğu unutulmamalıdır. Türkiye yine döviz kuru baskılarını azaltmak, dış finansman ihtiyaçlarını karşılamak ve döviz rezervlerindeki düşüşün önüne geçmek için gerekirse uluslararası kuruluşlarla masaya oturma kartını da elinde tutmak zorundadır.

Türkiye'nin krizden çıkaracağı belki de en önemli ders, kayıt dışı ekonominin yarattığı toplumsal, sosyal ve ekonomik tahribatın boyutlarını görmek ve bunun için gerekli çalışmaları bir an önce hayata geçirmektir.

Gerek yaşadığımız 2008 Küresel Krizi gerekse içinde bulunduğumuz Kovid-19 Küresel Krizi ile mücadelenin anahtarı toplumun birliği ve bütünlüğüdür. Ama bundan daha da önemli olan düzgün işleyen siyasal ve ekonomik kurumlarıdır. Siyasal ve ekonomik kurumlarının gücü toplumun gücünü ve devamlılığını yansıtan en önemli mekanizmalardır. Ülkenin üretici ve dinamik tüm kesimlerinin yılmadan, her hangi bir umutsuzluğa ve atalete kapılmadan, topyekûn mücadelesinin önünde hiçbir kriz direnemez.

\section{Kaynakça}

Acemoğlu D. ve Robinson J. A. (2016). Ulusların Düşüşü, Güç, Zenginlik ve Yoksulluğun Kökenleri, İstanbul: Doğan Egmont Yayımcılık.
Açıkgöz, Ö. \& Günay, A. (2020). The Early Impact of the Covid-19 Pandemic on the Global and Turkish Economy. Turkish Journal of Medical Sciences, 50, 520-526. doi:10.3906/sag-2004-6

Afşar, M. (2011, Ekim). Küresel Kriz ve Türk Bankacılık Sektörüne Yansımaları, Eskişehir Orhangazi Üniversitesi IIBBF Dergisi, 143-171.

Aşık G.A. ve Sayan S. (2020, Nisan). Korona Günlerinde İstihdamı ve Kırılgan Kesimleri Korumak, TEPAV Politika Notu, 1-8.

Ay H. ve Uçar Ö. (2015). Üç Küresel Ekonomik Krizin Analizi, Dokuz Eylül Üniversitesi Sosyal Bilimler Enstitüsü Dergisi, 17, 11-32

Bayar A.A. , Günçavdı Ö. ve Levent H. (2020, Nisan). Covid-19 salgınının Türkiye'de Gelir Dağılımına Etkisi ve Mevcut Politika Seçenekleri, ISTANPOL Politika Raporu, 007, 1-23

Bloomberg (2020). Erişim tarihi: 04.05.202, https://www.bloomberght.com/altin-7-haftanin-enbuyuk-haftalik-dususune-hazirlaniyor-2254416

Buluş A. ve Kabaklarlı E. (2010), 1929 Ekonomik Buhranı ile Son Dönem Global Krizin Karşılaştırılması, Sosyal Ekonomik Araştırmalar Dergisi, 10 (19), 122.

Dağlı O. (2020). Koronavirüs Salgını ve Çin-Afrika İlişkilerine Olası Etkileri, AFAM (Afrika Araştırmacıları Derneği) Raporu, 7, 1-30

Demirbaş M. ve Sezgin F.H. (2010). Likidite Krizi Sürecinde Amerika Birleşik Devletleri, Avrupa Birliği'ne Üye Ülkeler ve Türkiye'deki Bankacıllk Sektörünün Karşılaştırmalı Etkinlik Analizi: 20062010 dönemi, Gazi Üniversitesi İ̈BF Dergisi, 12/3, $135-158$

Duman E. ve Işı1k, N. (2011). Krizlerin Anatomisi: 1929 Ekonomik buhranı ve 2008 Küresel Krizi'nin Karşılaştırılması. Yayınlanmamış Yüksek Lisans Tezi. T.C.

Dünya Bankası (20 Nisan 2020). Son Ekonomik Gelişmeler, (Son güncelleme 20 Nisan 2020). Erişim: 06.05.2020,

https://www.worldbank.org/tr/country/turkey/overvi ew\#3

Eryüzlü H. (2020). Covid-19 Ekonomik Etkileri ve Tedbirler: Türkiye'de "Helikopter Para" Uygulaması, Ekonomi Maliye İşletme Dergisi-20203(1). Doi: $10.46737 /$ emid.745621, 10-19

European Economic Forecast Spring (2020, May). Istitutional Paper, 1-216.

Gern, KJ \& Hauber P. (2020). Konjunkturschlaglicht Coronavirus Hält Weltkonjunktur in Atem, $Z B W$ Leibniz-Informationszentrum Wirtschaft, 
Ökonomische Trends, 100 (3), 223-224. doi: 10.107/s10273-020-2607-5.

Gupta M., Abdelmaksoud A. , Jafferany M. , Lotti T. , Sadoughifar R. And Goldust M. (2020, March). Covid-19 and ekonomy, Dermatologic Therapy Wiley, Leter, 1. doi: 10.1111/dth.13329.

IATA (7 Nisan 2020). IATA Raporu, Sivil Havacılık Genel Müdürlüğü, http://web.shgm.gov.tr/tr/haberler/6350iata-covid-19-nedeniyle-25-milyon-calisanin-isininrisk-altinda-oldugunu-acikladi

ILO (29.04.2020). ILO Monitor: COVID-19 and The World of Work. Third Edition Updated Estimates and Analysis, 1-23.

IMF (2020). Hites Ahir, Nicholas Blum, Daveide Furceri, Global Uncertainty Related to Coronavirus at Record High. Erişim Tarihi: 21.04.2020

Invest Yatırım (11 Mart 2020). Coronavirus'un Finansal Piyasalara Etkisi. Erişim tarihi: 09.05.2020, https://www.investaz.com.tr/blog/corona-koronavirusunun-finansal-piyasalara-etkisi/

İnam, A. (26.03. 2020). Korona Öldürecek mi? Olduracak $m \imath$ ? Erişim tarihi: 21.04.2020, https://fikirturu.com/2020/03/26/korona-oldurecekmi-olduracak-mi/

İsmailoğlu, M. ve Çetin, M. (2012). 2008 Küresel Krizi Sonrası Avrupa'da Yükselen Popülist Hareketler. Yayınlanmamış Yüksek Lisans Tezi. İstanbul Üniversitesi Sosyal Bilimler Enstitüsü Avrupa Birliği Ana Bilim Dalı, İstanbul.

Karabıyık L. ve Anbar A. (2010). Küresel Ekonomik Krizin Doğrudan Yabanc1 Yatırımlar Üzerindeki Etkisi, Muhasebe ve Finansman Dergisi, 46, 44-57.

Karamanoğlu Mehmetbey Üniversitesi Sosyal Bilimler Enstitüsü, Karaman.

Kaykusuz M. (2016). İktisadi Kriz Teorileri, Bursa: Ekin Basın Yayın Dağıtım.

Kentikelenis A., Gabor D., Ortiz I., Stubbs T., McKee M. and Stuckler D. (2020, April). Softening the outbreak of the outbreak: Will the International Monetary Fund and the World Bank make things worse?, Lancet Global Health 2020 Comment. 1-2. https://doi.org/10.1016/S2214-109X(20)30135-2

Kickbusch I. Leung G.M, Bhutta Z.A., Matsoso M. P. , Ihekweazu C.And Abbasi K. (2020, April). Covid19: How a Virus is Turning The World Upside Down, BMJ 2020 Editorials, 1-3. doi: 10.1136/bmj.m1336.

Kutlu, H. A. ve Demirci N.S. (2011, Ekim). Küresel Finansal Krizi (2007-?) Ortaya Çıkaran Nedenler, Krizin Etkileri, Krizden Kısmi Çıkış ve Mevcut Durum. Muhasebe ve Finansman Dergisi, 121-136.
McKee M. \& Stuckler D. (2020, April). Covid-19 will Damage Health Not Just Now But Also In The Future, Nature Medicine, 1-3. https://doi.org/10.1038/s41591-020-0863-y

OECD (2019). Economic Surveys: Chine 2019, 8. Doi:https://doi.org/10.1787/eco_surveys-chn-2019en https://read.oecd-ilibrary.org/economics/oecdeconomic-surveys-china-2019_eco_surveys-chn2019-en\#page10

OECD (02.03.2020). Interim Economic Assessment Coronavirus: The world economy at risk, 1-18.

Özatay F. ve Sak G., (2020, Mayı), COVID 19 ve Normalleşme, Türkiye Ekonomi Politikalar Araştırma Vakfi (TEPAV) Politika Notu, 1-6.

Öztürk, S., Özdemir, A. and Ülger Ö. (2011). Küresel Ekonomik Kriz ve Türkiye'nin Para Politikaları Üzerine Etkileri, Internatıonal Conference On Eurasian Economies 2012, 298-303.

Pierce, B. (2020, March). COVID-19: Cash Born Analysis, IATA.

Polat A.M. (2018). Küresel Finansal Krizin Nedenleri, Injosos Al-Farabi Internatıonal Journal On Social Sclences, 2/1, 177-195.

Rystad Energy (29 April 2020). Covid-19 Report 8th Edition, Global Outbreak Overview and Its Impact on the Energy Sector, Public Version, 1-24.

Takım, A. (2011). Küresel Krizin Türkiye'de Finansal Kesim Üzerindeki Etkileri, Elektronik Sosyal Bilimler Dergisi, 10:35, 337-352.

Topbaş N. (2009). Finansal Kriz Ortamında Bankaların Muhasebe Sistemlerinde Gerçeğe Uygun Değerleme Yönteminin etkileri, Bankacılar Dergisi, 68, 56-64.

T.C. Hazine ve Maliye Bakanlığı (2020).Erişim: 16.10.2020. https://www.hmb.gov.tr/kamu-finansmaniistatistikleri

T.C. Sağlık Bakanlığı (2020). Erişim:5.05.2020. https://covid19bilgi.saglik.gov.tr/tr/

TOBB (2009). Ekonomik Rapor (65. Genel Kurul) Yayın No: 2010 / 110, 1-153.

TÜİK (2020, Mart). Türkiye Istatistik Kurumu, Dış Ticaret istatistikleri, Mart 2020.

TÜİK (2020, Nisan), Türkiye Istatistik Kurumu, Tüketici Fiyat Endeksi, Nisan 2020.

TÜİK (2020, Nisan) Türkiye İstatistik Kurumu, İsgücü Istatistikleri, Nisan 2020.

Ulusoy K. M. (2020, Şubat). Koronavirüs'ün Ekonomik ve Finansal Etkileri, Stratejik Düşünce Enstitüsü SD Analiz. 
UNCTAD (2020, April). Trade and Development Report Update, From the Great Lockdown, to the Great Meltdown: Developing Country Debt in the Time of Covid-19, 1-16.

UNWTO (28 April 2020). COVID - 19 Related Travel Restrictions A Global Rewiev for Tourism Second Report as of 28 April 2020, 1-16.

Ünveren B. (31.03.2020) Koronovarise Karşı Hangi ülke Hangi Ekonomik Önlemi Ald $\imath$ ? Erişim tarihi: 21.04.2020,

https://www.dw.com/tr/koronavir\%C3\%BCsekar\%C5\%9F\%C4\%B1-hangi-\%C3\%BClke-hangiekonomik-\%C3\%B6nlemi-ald\%C4\%B1/a-52969655

WHO (26.04.2020) tarihli, 97 Sayılı Durum Raporu. Erişim tarihi: 27.04.2020 https://www.who.int/docs/defaultsource/coronaviruse/situation-reports/20200426sitrep-97-covid-19.pdf?sfvrsn=d1c3e800_6
WWTC (2020). WTTC Covid-19 Impact 2020, Erişim: 03.05.2020 https://wttc.org/en-gb/COVID19/Recovery-Post-COVID-19

Yavuz, A., Şataf, C. ve Kır, S. (2013). Avrupa'da Borç Krizi ve Çözüm Arayışları, Afyon Kocatepe Üniversitesi İktisadi ve İdari Bilimler Fakültesi Dergisi, 15 (2), 131-154.

Yeldan, E. (2009). Kapitalizmin Yeniden Finansallaşması ve 2007/2008 Krizi: Türkiye Krizin Neresinde?, Çalışma ve Toplum Dergisi, 20, 1-18.

Yıldırım, S. (2010). 2008 Yılı Küresel Ekonomi Krizinin Dünya ve Türkiye Ekonomisine Etkileri. Karamanoğlu Mehmetbey Üniversitesi Sosyal ve Ekonomik Araştırmalar Dergisi, (1), 47-55.

Yıldız, Z. ve Durgun A. (2010). 2008 Küresel Krizi ve Turizm Sektörü Üzerine Etkileri, Süleyman Demirel Üniversitesi Vizyoner Dergisi, 2 (1), 1-15. 